\title{
PREPARATION AND CHARACTERISATION OF ACTIVATED CARBON FROM PUMPKIN SEED SHELL USING $\mathrm{H}_{3} \mathrm{PO}_{4}$
}

\author{
İlknur DEMIRAL ${ }^{1, *}$, Canan AYDIN ŞAMDAN ${ }^{1}$ \\ ${ }^{1}$ Department of Chemical Engineering, Engineering and Architecture Faculty, \\ Eskişehir Osmangazi University, 26480 Eskişehir, Turkey
}

\begin{abstract}
In this study, activated carbons were produced from pumpkin seed shell by chemical activation. In chemical activation, $\mathrm{H}_{3} \mathrm{PO}_{4}$ was used as chemical agent. The effects of impregnation ratio (IR) and activation temperature were investigated. Activation temperatures and impregnation ratios were selected in the range of $400-600{ }^{\circ} \mathrm{C}$ and $1-3$, respectively. The surface area, pore volumes, pore size distribution and average pore diameter of the activated carbons were characterized by $\mathrm{N}_{2}$ adsorption at 77 $\mathrm{K}$ using the BET, $t$-plot and DFT methods. The highest BET surface area and total pore volume of the activated carbon was obtained as $1421 \mathrm{~m}^{2} / \mathrm{g}$ and $0.908 \mathrm{~cm}^{3} / \mathrm{g}$ at $500{ }^{\circ} \mathrm{C}$ activation temperature and at an impregnation ratio of 2 , respectively. The morphology and functional groups present were investigated by scanning electron microscope (SEM) and Fourier transform infrared (FTIR) spectroscopy. The experimental results show that the activation temperature and the impregnation ratio have a significant effect on the pore structure of the activated carbon and pumpkin seed shell seemed to be an alternative precursor for the commercial activated carbon productions.
\end{abstract}

Keywords: Pumpkin seed shell, Chemical activation, Activated carbon, Textural characterization

\section{KABAK ÇEKİRDEĞİ KABUĞUNDAN $\mathrm{H}_{3} \mathrm{PO}_{4}$ KULLANARAK AKTIF KARBON HAZIRLANMASI VE KARAKTERIZASYONU}

\begin{abstract}
ÖZET
Bu çalışmada kabak çekirdeği kabuğundan kimyasal aktivasyon ile aktif karbon üretilmiştir. Kimyasal aktivasyonda kimyasal olarak $\mathrm{H}_{3} \mathrm{PO}_{4}$ kullanılmıştır. Emdirme oranı ve aktivasyon sıcaklığının etkileri incelenmiştir. Aktivasyon sıcaklığı ve emdirme oranı sırasıyla $400-600{ }^{\circ} \mathrm{C}$ ve 1-3 olarak seçilmiştir. Aktif karbonun yüzey alanı, gözenek hacmi, gözenek boyut dağılımı ve ortalama gözenek çap $77 \mathrm{~K}$ de azot adsorpsiyonu ile BET, $t$-plot ve DFT yöntemleri kullanılarak karakterize edilmiştir. Aktif karbonun en yüksek BET yüzey alanı ve toplam gözenek hacmi $500{ }^{\circ} \mathrm{C}$ aktivasyon sıcaklı̆̆ 1 ve emdirme oranı 2 de sirasıyla $1421 \mathrm{~m}^{2} / \mathrm{g}$ ve $0.908 \mathrm{~cm}^{3} / \mathrm{g}$ olarak elde edilmiştir. Yüzey morfolojisi ve fonksiyonel grupları taramalı electron mikroskobu (SEM) ve Fourier transform infrared spektroskopisi (FTIR) ile incelenmiştir. Deneysel sonuçlar aktivasyon sicaklığı ve emdirme oranının aktif karbonun gözenek yapısında önemli etkiye sahip olduğu ve kabak çekirdeği kabuğunun ticari aktif karbon üretimi için alternatif hammadde olduğunu göstermiştir.
\end{abstract}

Anahtar Kelimeler: Kabak çekirdeği kabuğu, Kimyasal aktivasyon, Aktif karbon, Yapısal karakterizasyon

\section{INTRODUCTION}

Activated carbon is a high porosity material which is useful in adsorption of both gases and solutes from aqueous solutions. Therefore, it has been widely used for the separation of gases, the recovery of solvents, and the removal of organic pollutants from drinking water and as a catalyst support [1]. Activated carbons are used as adsorbent materials because of their large surface areas, microporous structures, high degree of surface reactivities and high adsorption capacities [2]. Generally, activated carbon is mainly a microporous solid but, in addition to micropores, it contains meso and macropores, which are very important pores in facilitating access of the adsorbate molecules to the interior of carbon particles [3].

\footnotetext{
* Corresponding Author: idemiral@ogu.edu.tr
} 
Various types of precursors are used to produce activated carbon. These precursors are generally fossil based hydrocarbons (such as bituminous coal, lignite), natural biomass (lignocellulosic materials), biomass waste, polymers and carbonaceous wastes. The use of natural biomass is important as it is the most abundant renewable raw material. The quality and characteristics of activated carbons depend on the physical and chemical properties of the starting materials, the activation methods (chemical or physical), the activation agent and the heat treatment process [4,5].

Activated carbon can be produced theoretically from any carbonaceous material rich in elemental carbon. In recent years, there has been considerable research concerning the preparation of activated carbon from different precursors such as agricultural byproducts [2], pumpkin seed shell [6], cherry stones [7], corn grain [8], waste tea [9], orange skin [10], Paulownia wood [11], and coconut shell [12].

Activated carbons can be produced basically by two methods: physical activation or chemical activation. Physical activation involves primary carbonization of the raw material (below $700{ }^{\circ} \mathrm{C}$ ) followed by controlled gasification at higher temperatures $\left(>850^{\circ} \mathrm{C}\right.$ ) in a stream of an oxidizing gas (steam, $\mathrm{CO}_{2}$, air or a mixture) [13]. The chemical activation is carried out by impregnation of the precursor with a chemical such as $\mathrm{KOH}$ [14], $\mathrm{K}_{2} \mathrm{CO}_{3}$ [15], $\mathrm{NaOH}$ [16], $\mathrm{Na}_{2} \mathrm{CO}_{3}$ [17], $\mathrm{H}_{2} \mathrm{SO}_{4}$ [18,19], $\mathrm{ZnCl}_{2}$ [20,21] and $\mathrm{H}_{3} \mathrm{PO}_{4}[4,22]$ and then heat-treatment at moderate temperatures in a one step process. Chemical activation is preferred over physical activation owing to higher activated carbon yield, lower activation temperature and shorter activation time, and good development of the porous structure [11,23]. Among the chemical activating agents, phosphoric acid is one of the most widely used chemicals in the preparation of activated carbon. Phosphoric acid has been preferred recently due to environmental and economic concerns [24]. Moreover, $\mathrm{H}_{3} \mathrm{PO}_{4}$ allows the developing both micropores and mesopores in the resulting activated carbon [25]. Phosphoric acid activation has been applied to different biomass materials $[4,22,26]$.

In this study, activated carbons were produced from pumpkin seed shell by chemical activation with phosphoric acid. The effects of carbonization temperature and impregnation ratio on the pore structure (specific surface area, pore volume and pore size distribution) were investigated. In addition, the produced activated carbons were characterized by various techniques such as elemental analysis, $\mathrm{N}_{2}$ adsorption, FTIR and SEM.

\section{METHODS}

\subsection{Material}

The pumpkin seed shell used in this study was the pumpkin seed process waste of Peyman Company which produces all kinds of nuts and dried fruits in Eskişehir, Turkey. Prior to the experiments, the sample was air dried, ground in a high speed rotary cutting mill (Retsch) and then screen analysis was applied to obtain mean particle size of $0.850<\mathrm{Dp}<1.000 \mathrm{~mm}$. The proximate analysis (moisture, ash and volatile matter content) of the pumpkin seed shell was carried out according to ASTM standart test methods. The carbon, hydrogen and nitrogen contents of the pumpkin seed shell and activated carbon were measured using LECO-CHNS-932 elemental analyzer.

\subsection{Preparation of Activated Carbon}

In this study, the chemical activation of pumpkin seed shell was carried out using $\mathrm{H}_{3} \mathrm{PO}_{4}$. The impregnation ratio was calculated as the ratio of the weight of $\mathrm{H}_{3} \mathrm{PO}_{4}$ in solution to the weight of the dried pumpkin seed shell. The impregnation ratio was varied between 1 and 3 . Twenty to sixty grams of $\mathrm{H}_{3} \mathrm{PO}_{4}$ ( $85 \mathrm{wt} . \%$, provided by Merck) were dissolved in $200 \mathrm{~mL}$ of distilled water, and then $20 \mathrm{~g}$ of the raw material was mixed with the $\mathrm{H}_{3} \mathrm{PO}_{4}$ solution and stirred at approximately $70^{\circ} \mathrm{C}$ for $6 \mathrm{~h}$ to ensure a completed reaction between $\mathrm{H}_{3} \mathrm{PO}_{4}$ and shell particles. After treatment the mixtures were then filtered 
and the remaining solids were dried at $105^{\circ} \mathrm{C}$ for about $24 \mathrm{~h}$. Chemical impregnated pumpkin seed shell was placed in a vertical3three zone tubular furnace (Carbolite, UK) and then carbonized at the desired final carbonization temperatures $\left(400,500\right.$ and $\left.600{ }^{\circ} \mathrm{C}\right)$ under the nitrogen flow of $100 \mathrm{~mL} / \mathrm{min}$. The carbonization process was initiated by heating the impregnated sample with a heating rate of $10^{\circ} \mathrm{C} / \mathrm{min}$ starting from room temperature until the desired final carbonization temperature was reached. The samples were held at the desired temperature for $1 \mathrm{~h}$. Then the temperature of the reactor was cooled down to the room temperature under nitrogen atmosphere. The produced carbonization material was washed sequentially several times with hot distilled water until the $\mathrm{pH}$ of the washing solution reached a value between 6 and 7 . They were then dried at $110{ }^{\circ} \mathrm{C}$ for 24 hours, and weighed to calculate the activated carbon yield.

\subsection{Characterization of the Activated Carbons}

Characterization of activated carbons was carried out by nitrogen adsorption-desorption isotherms measured at $77 \mathrm{~K}$ using Quantachrome, Autosorb 1C. Prior to gas adsorption measurement, the samples were degassed at $300{ }^{\circ} \mathrm{C}$ under vacuum for $3 \mathrm{~h}$. The adsorption data were obtained in a relative pressure, $\mathrm{P} / \mathrm{Po}$, range of $10^{-5}$ to 1 . The BET surface area was calculated from $\mathrm{N}_{2}$ adsorption isotherms by using the Brunauer-Emmett-Teller (BET) equation within the 0.01-0.15 relative pressure range. The t-plot method was applied to calculate the micropore volume. The total pore volumes were calculated at a relative pressure of 0.995 . The pore size distributions of the activated carbons were determined by DFT (Density Functional Theory) method. The FTIR spectra were recorded using an infrared spectrometer (Perkin Elmer100) between 4000 and $400 \mathrm{~cm}^{-1}$. Scanning electron microscopy (SEM) analysis of the pumpkin seed shell and the activated carbon was carried out to examine its surface and the development of porosity (JEOL-JSM-5600LV model SEM).

\section{RESULTS AND DISCUSSION}

The results of the proximate and ultimate analyses of the pumpkin seed shell are given in Table 1.

As can be seen from Table 1, pumpkin seed shell is characterized by low ash, high volatile matter, high carbon and zero sulfur contents. The high volatile matter and low ash content of biomass resources make them good starting materials for preparing activated carbon [27]. Pumpkin seed shell may be considered as a suitable precursor for conversion to activated carbon.

Table 1. Proximate and ultimate analyses (wt.\%) of pumpkin seed shell

\begin{tabular}{lcl}
\hline Characteristics & Percentage (wt.\%) & Methods \\
\hline Proximate analysis & & \\
Moisture content & 7.60 & ASTM D 4442-92 \\
Volatiles $\quad$ Ash & 3.90 & ASTM E 897-82 \\
Fixed carbon ${ }^{\mathrm{a}}$ & 17.53 & ASTM D 1102-84 \\
& & \\
Ultimate analysis & & LECO elemental analyzer \\
Carbon & 48.79 & \\
Hydrogen & 7.52 & \\
Nitrogen & 3.97 & \\
Oxygen & 39.72 & \\
\hline${ }^{a}$ By difference & &
\end{tabular}




\subsection{Yield of Activated Carbon}

The yield of activated carbon was calculated from the weight of resultant activated carbons divided by the weight of dried pumpkin seed shell. Figure 1 shows the effects of the activation temperature and impregnation ratio on the yield of activated carbon.

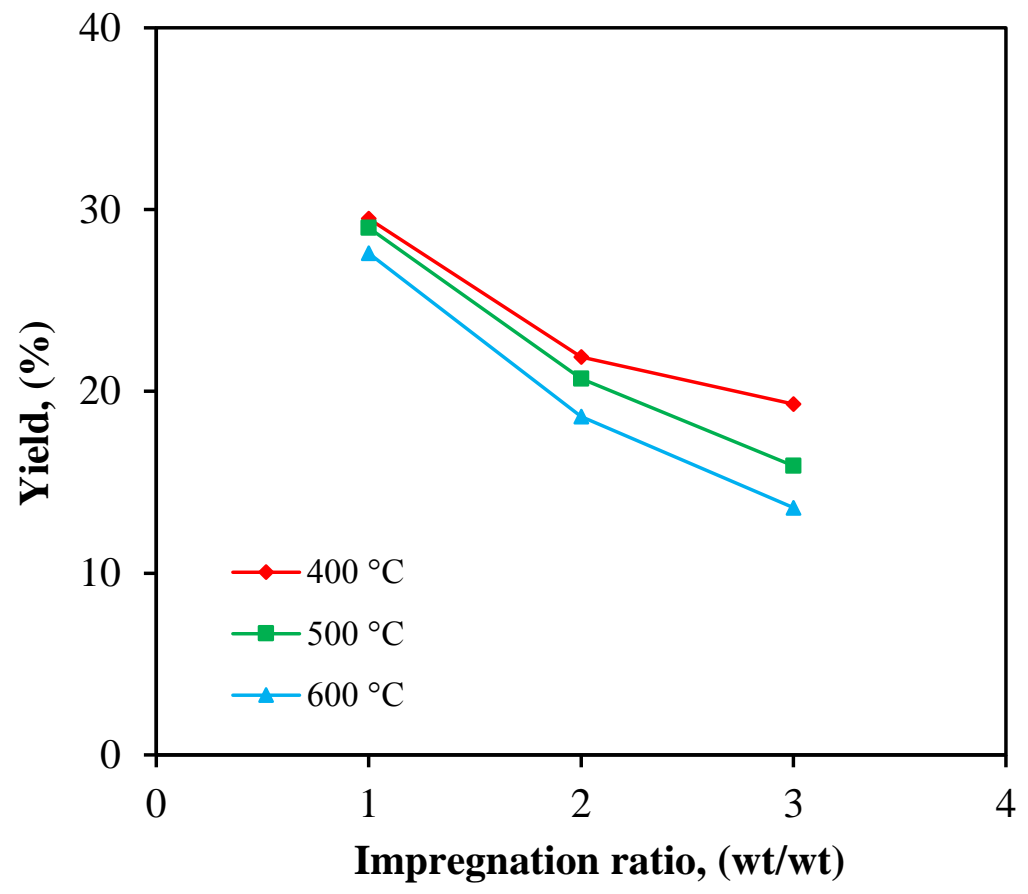

Figure 1. The effect of temperature and impregnation ratio on the yield of activated carbon

The final carbonization temperature and impregnation ratio play an important role on the yield of activated carbon. It can be seen from Figure 1 that, with increasing activation temperature, the yields of activated carbon decrease as the weight loss rate is higher primarily due to the initial large amount of volatiles that can be easily released with higher temperature as well as the loss of moisture to a lesser extent [28]. In each carbonization temperature, activated carbon yields are decreasing with increasing impregnation ratio. As the impregnation ratio increases, the percentage yield of the activated carbon decreases gradually due to the continuous removal of tar material from the pores [23]. This behavior agrees with results obtained by Prahas et al. [29] for activated carbon production from jackfruit peel waste by chemical activation with $\mathrm{H}_{3} \mathrm{PO}_{4}$. The lower yield with the higher $\mathrm{H}_{3} \mathrm{PO}_{4} /$ pumpkin seed shell ratio might be caused by the enhancement of carbon burning-off by extra $\mathrm{H}_{3} \mathrm{PO}_{4}$.

\subsection{Elemental Analysis of the Produced Activated Carbon}

Table 2 summarizes the elemental composition of activated carbons prepared from pumpkin seed shell at different activation temperatures and impregnation ratios. Activated carbons have higher carbon content than pumpkin seed shell which makes them more carbonaceous material.

As can be seen from Table 2, with an increase in the activation temperatures from 400 to $500{ }^{\circ} \mathrm{C}$, the carbon content of the activated carbon samples increased from 60.86 to $66.10 \mathrm{wt} \%$ and then decreased to $64.38 \mathrm{wt} \%$ at $600{ }^{\circ} \mathrm{C}$. The decrease in the carbon content from $66.10 \mathrm{wt} \%$ at $500{ }^{\circ} \mathrm{C}$ to $64.38 \mathrm{wt} \%$ at $600{ }^{\circ} \mathrm{C}$ can be suggested to be due to volatilisation of phosphorus compounds and the partial gasification of the carbon by $\mathrm{P}_{2} \mathrm{O}_{5}$, which leads to the reduction of the carbon content. Similar results were obtained by other researchers $[30,31]$. 
When the impregnation ratio varied from 1 to 3 the content of hydrogen increased from $2.76 \%$ to $3.26 \%$ and the content of carbon also increased from $60.64 \%$ to $72.38 \%$. On the contrary the nitrogen content decreased from $2.51 \%$ to $1.52 \%$. These findings show that the use of excess amount of $\mathrm{H}_{3} \mathrm{PO}_{4}$ favoured the compounds having hydrogen and eliminated nitrogenous compounds. High carbon content also indicates that aromatic structure becomes dominant when much amount of $\mathrm{H}_{3} \mathrm{PO}_{4}$ is used [30].

Table 2. Elemental analyses of activated carbons produced at different activation temperatures and impregnation ratios

\begin{tabular}{ccccc}
\hline $\mathrm{H}_{3} \mathrm{PO}_{4}$ impregnation ratio: 2 & \multicolumn{5}{c}{ wt.\% } \\
\hline Activation Temperature $\left({ }^{\circ} \mathrm{C}\right)$ & Carbon & Hydrogen & Nitrogen & Oxygen $^{\mathrm{a}}$ \\
\cline { 2 - 5 } 400 & 60.86 & 3.07 & 2.78 & 33.29 \\
500 & 66.10 & 2.62 & 2.05 & 29.23 \\
600 & 64.38 & 3.15 & 2.26 & 30.21 \\
\hline Activation Temperature:500 ${ }^{\circ} \mathrm{C}$ & \multicolumn{4}{c}{ wt.\% } \\
\hline Impregnation ratio & Carbon & Hydrogen & Nitrogen & Oxygen $^{\text {a }}$ \\
1 & 60.64 & 2.76 & 2.51 & 34.09 \\
2 & 66.10 & 2.62 & 2.05 & 29.23 \\
3 & 72.38 & 3.26 & 1.52 & 22.84 \\
\hline
\end{tabular}

\footnotetext{
${ }^{a}$ By difference
}

In all activated carbons, the contents of carbon were increased whereas the contents of hydrogen were decreased when compared to the raw material. This is due to the release of volatiles during carbonization that resulted in the elimination of non-carbonaceous parts and enrichment of carbon [32].

\section{4. $\mathbf{N}_{2}$ Adsorption-Desorption Isotherms}

The shape of adsorption isotherm can provide preliminary qualitative information on the adsorption mechanism as well as on the porous structure of carbon. These isotherms clearly show the predominantly microporous nature of the carbons, with some mesopores leading to gradual increase in adsorption after the initial filling of the micropores, followed by more rapid enhancement near saturation. The $\mathrm{N}_{2}$ adsorption-desorption isotherms of the activated carbons obtained at different temperatures and impregnation ratios are shown in Figure 2 and 3 respectively. Nitrogen adsorption isotherms of these activated carbons can be properly classified as a mixture of type I and type IV isotherms. According to IUPAC classification, type I isotherm can be associated with microporous structure while type IV isotherm exhibited by mixture of microporous and mesoporous materials [31]. It was clearly demonstrated that the amount of adsorbed nitrogen was found to increase rapidly even at relative pressure lower than 0.1. In the initial part of each isotherm, all isotherms are type I, with an important uptake at low relative pressure, the characteristics of microporous materials. Furthermore, as the relative pressure increases to 0.4 , the isotherms exhibit apparent hysteresis loops. This adsorption behavior exhibits a type IV isotherm as characteristic of mesoporous structure. The slope of the plateaus in these isotherms gradually increases with increasing relative pressure. Therefore, the activated carbons obtained at various final activation temperatures show both microporous and mesoporous structures.

Figure 2 shows that with increasing carbonization temperature up to $500{ }^{\circ} \mathrm{C}$ there is an upward trend in adsorption, that is to say, the surface area increases. As the carbonization temperature increases from $500{ }^{\circ} \mathrm{C}$ to $600{ }^{\circ} \mathrm{C}$ the amount of nitrogen adsorbed by the activated carbons decreases. 


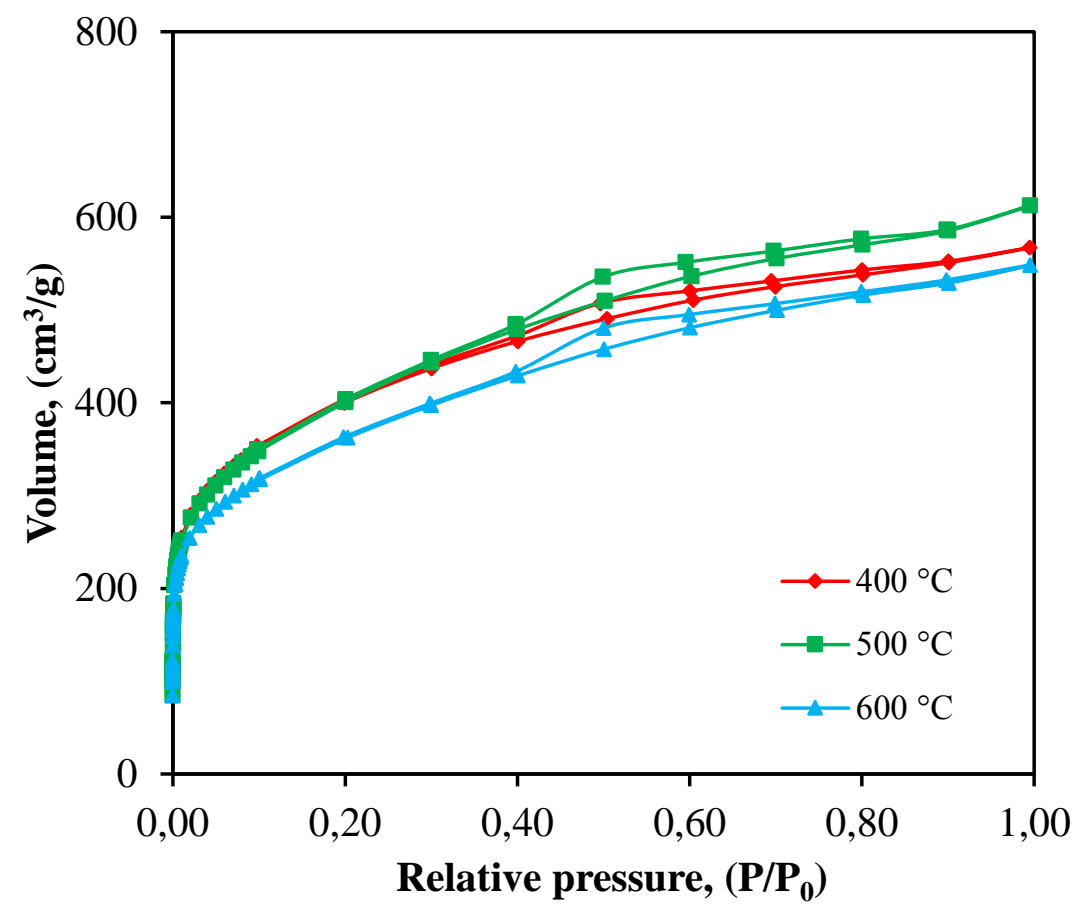

Figure 2. Adsorption-desorption isotherms of the activated carbons obtained at different temperatures (impregnation ratio: 2)

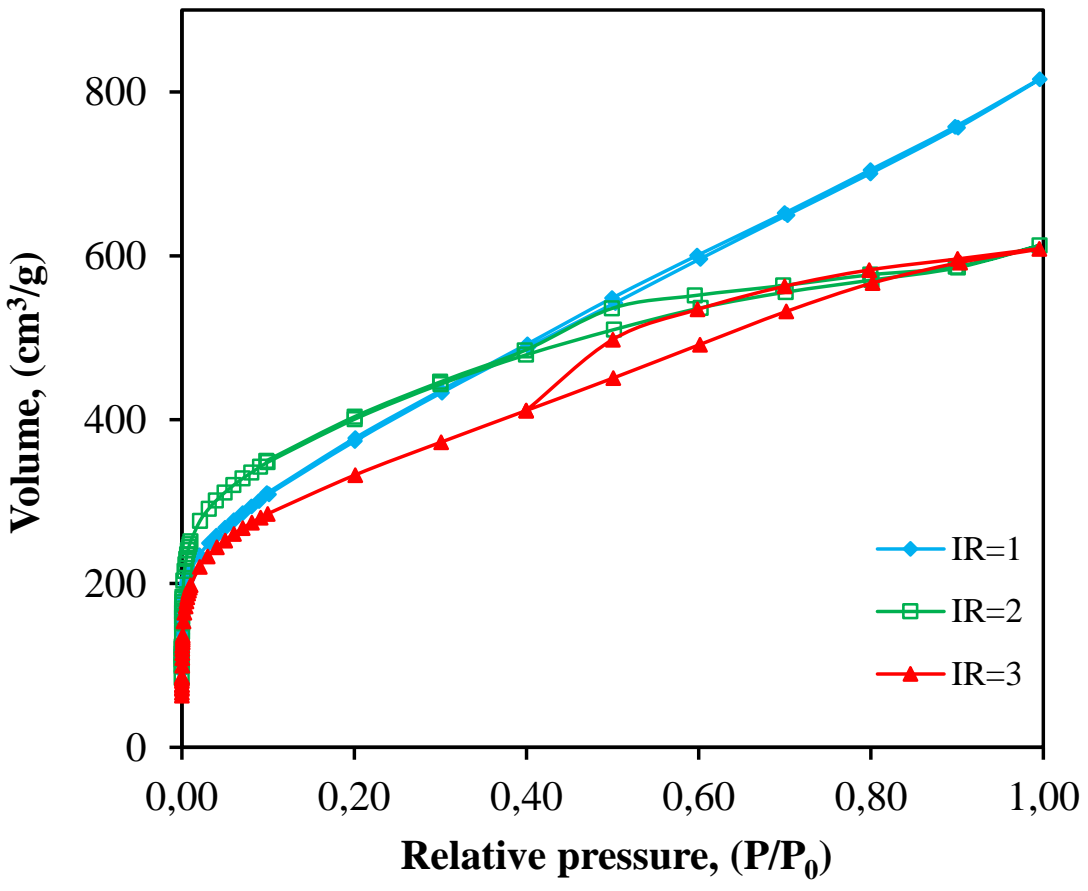

Figure 3. Adsorption-desorption isotherms of the activated carbons obtained at different impregnation ratio (activation temperature: $500{ }^{\circ} \mathrm{C}$ ) 


\subsection{The Effects of Activation Temperature and Impregnation Ratio on the Surface Area and Pore Volume}

Activation temperature and impregnation ratio are the most important parameters for activated carbon production. Table 3 presents the textural parameters of the activated carbons prepared at different conditions. It is obvious from the data shown in Table 3 that using phosphoric acid as an activating agent is very efficient to produce activated carbons with high porosity.

Table 3. Surface properties of the activated carbons

\begin{tabular}{cccccc}
\hline $\begin{array}{c}\text { Impregnation } \\
\text { ratio } \\
(\mathrm{wt} / \mathrm{wt})\end{array}$ & $\begin{array}{c}\text { Activation } \\
\text { temperature } \\
\left({ }^{\circ} \mathrm{C}\right)\end{array}$ & $\begin{array}{c}\mathrm{S}_{\mathrm{BET}} \\
\left(\mathrm{m}^{2} / \mathrm{g}\right)\end{array}$ & $\begin{array}{c}\mathrm{V}_{\text {tot }} \\
\left(\mathrm{cm}^{3} / \mathrm{g}\right)\end{array}$ & $\begin{array}{c}\mathrm{V}_{\text {mic }} \\
\left(\mathrm{cm}^{3} / \mathrm{g}\right)\end{array}$ & $\begin{array}{c}\mathrm{Dp} \\
(\AA)\end{array}$ \\
\hline 1 & 500 & 1252 & 0.4569 & 0.3891 & 23,31 \\
2 & 400 & 1407 & 0,8797 & 0,4752 & 24,83 \\
2 & 500 & 1421 & 0,908 & 0,4817 & 25,81 \\
2 & 600 & 1269 & 0,820 & 0,4401 & 26.79 \\
3 & 500 & 1406 & 0,868 & 0,4728 & 34.79 \\
\hline
\end{tabular}

The effect of activation temperature on the surface area, total pore volume and micropore volume was evaluated at the impregnation ratio of 2 . The effect of activation temperature on the BET surface area, total pore volume and micropore volume was given in Figure 4. The surface area increased from 1407 to $1421 \mathrm{~m}^{2} / \mathrm{g}$ as the temperature was increased from 400 to $500{ }^{\circ} \mathrm{C}$ and then decreased to $1269 \mathrm{~m}^{2} / \mathrm{g}$ at $600{ }^{\circ} \mathrm{C}$. The micropore volume and total pore volume followed the same trend. The BET surface areas and pore volumes of the samples reach their maximum values at a temperature of $500{ }^{\circ} \mathrm{C}$. The increase of surface area with temperature up to $500{ }^{\circ} \mathrm{C}$ may correspond to the evolution of compounds produced from the cross-linking reactions. The decrease above $500{ }^{\circ} \mathrm{C}$ were attributed to the degradation of the phosphate and polyphosphate bridges or the collapse of the resultant carbon samples [33]. As the temperature increases to $600{ }^{\circ} \mathrm{C}$, not only aromatization in the carbonaceous structure occurs as a result of the carbonization process, but also phosphorus involved in the activation process stabilize thermally, and this has an unfavorable effect on the surface area and porosity. This indicates that pore formation is affected by both the reaction between incorporated $\mathrm{H}_{3} \mathrm{PO}_{4}$ and the precursor, and thermal pyrolysis of the precursor. $500{ }^{\circ} \mathrm{C}$ was obtained as the best temperature in the range studied. In literature, activation temperature of $450-500{ }^{\circ} \mathrm{C}$ was determined as better temperature by various researchers for different materials [34,35]

It is obvious from the data shown in Table 3 that using phosphoric acid as an activating agent is very efficient to produce activated carbons with high porosity and that the impregnation ratio has a significant influence on porosity development. The effect of impregnation ratio was investigated using the activated carbons prepared at $500{ }^{\circ} \mathrm{C}$. The effect of impregnation ratio on the BET surface area, total pore volume and micropore volume was given in Figure 5. In chemically activating with phosphoric acid, it is well known that the impregnation ratio is one of the variables having a profound effect on the porosity of the final carbons [22].

As the impregnation ratio was increased from 1 to 2 , surface area of the activated carbons increased from 1252 to $1421 \mathrm{~m}^{2} / \mathrm{g}$. A similar trend was observed for the total and micropore volumes. An increase in the amount of activating agent promotes the contact area between pumpkin seed shell and activating agent which promotes the diffusion of phosphoric acid into the structure. This leads finally to an increase in the porosity. When the impregnation ratio increases to 3 , the porosity of the resultant activated carbon decreases. As the phosphoric acid dosage increased, more potential sites could be penetrated and occupied by the activating agent, which benefited the following pore opening and widening processes. However, excessive phosphoric acid could not promote the activation further since an insulating layer might be formed [36]. Furthermore, the existence of phosphate and polyphosphate species in the carbon 
matrix after washing may block some of the created pores. Similar results were obtained by other researchers $[22,31]$.

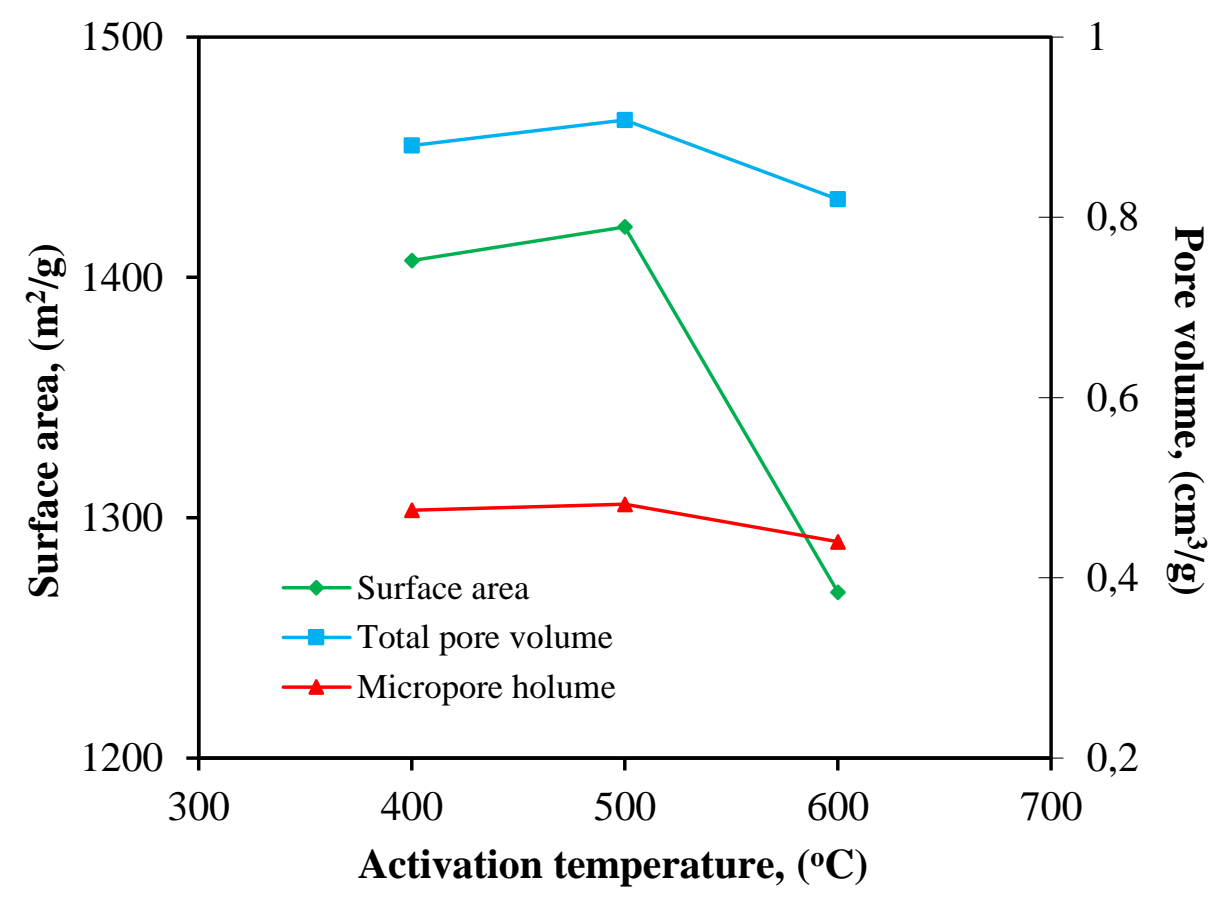

Figure 4. Effect of the activation temperature on the surface area, total pore volume and micropore volume (impregnation ratio:2)

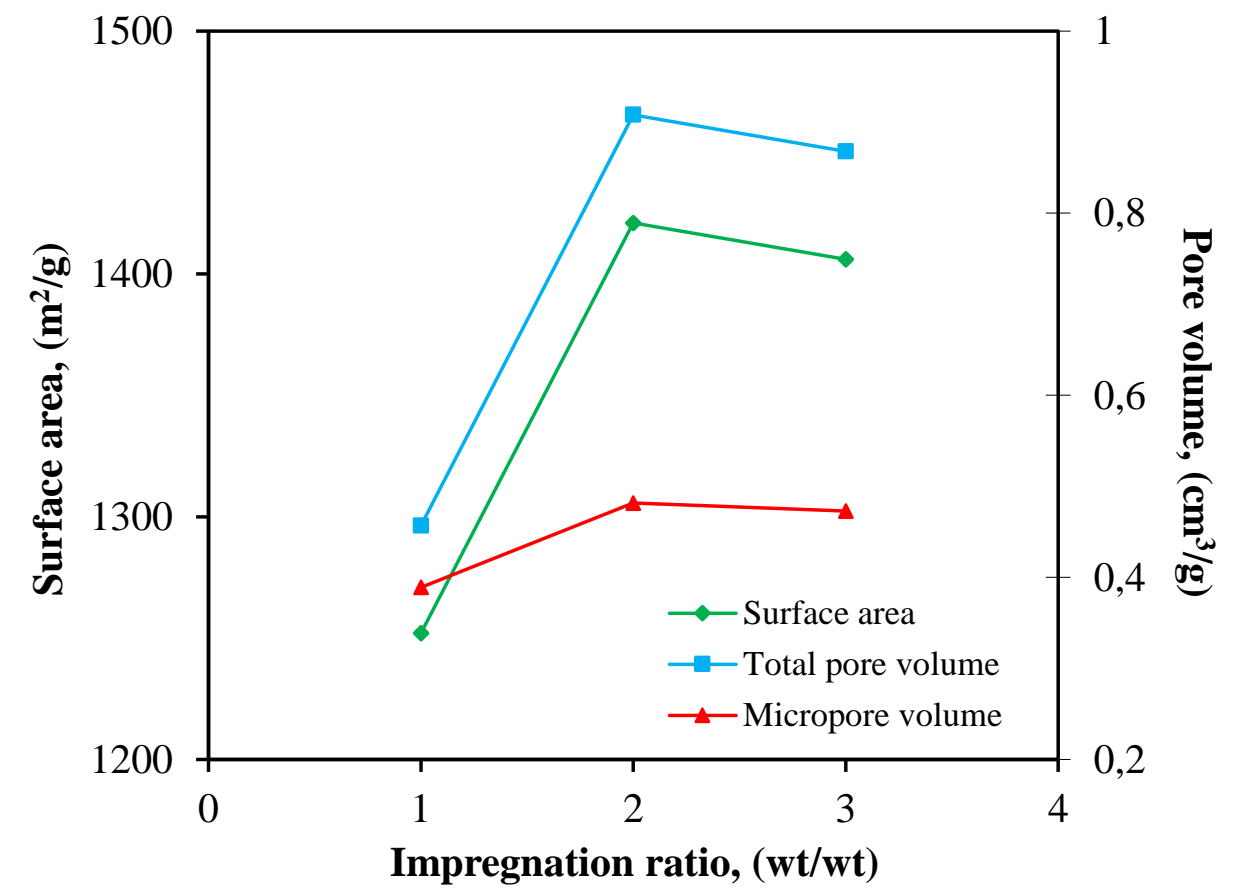

Figure 5. Effect of the impregnation ratio on the surface area, total pore volume and micropore volume (activation temperature:500 ${ }^{\circ} \mathrm{C}$ ) 


\subsection{Pore Size Distribution of the Activated Carbon}

The structural heterogeneity of porous material is generally characterized in terms of the pore size distribution. The pore size distribution of activated carbons produced from pumpkin seed shell at various impregnation ratios at carbonization temperature of $500{ }^{\circ} \mathrm{C}$ is given in Figure 6 . The pores of the adsorbents are generally classified into three groups, micropore (pore size $<2 \mathrm{~nm}$ ), mesopore $(2-50 \mathrm{~nm})$ and macropore (>50 nm) [37]. All activated carbons include both micropores and mesopores. However, the micropore volumes are larger than mesopore volumes for all carbons.

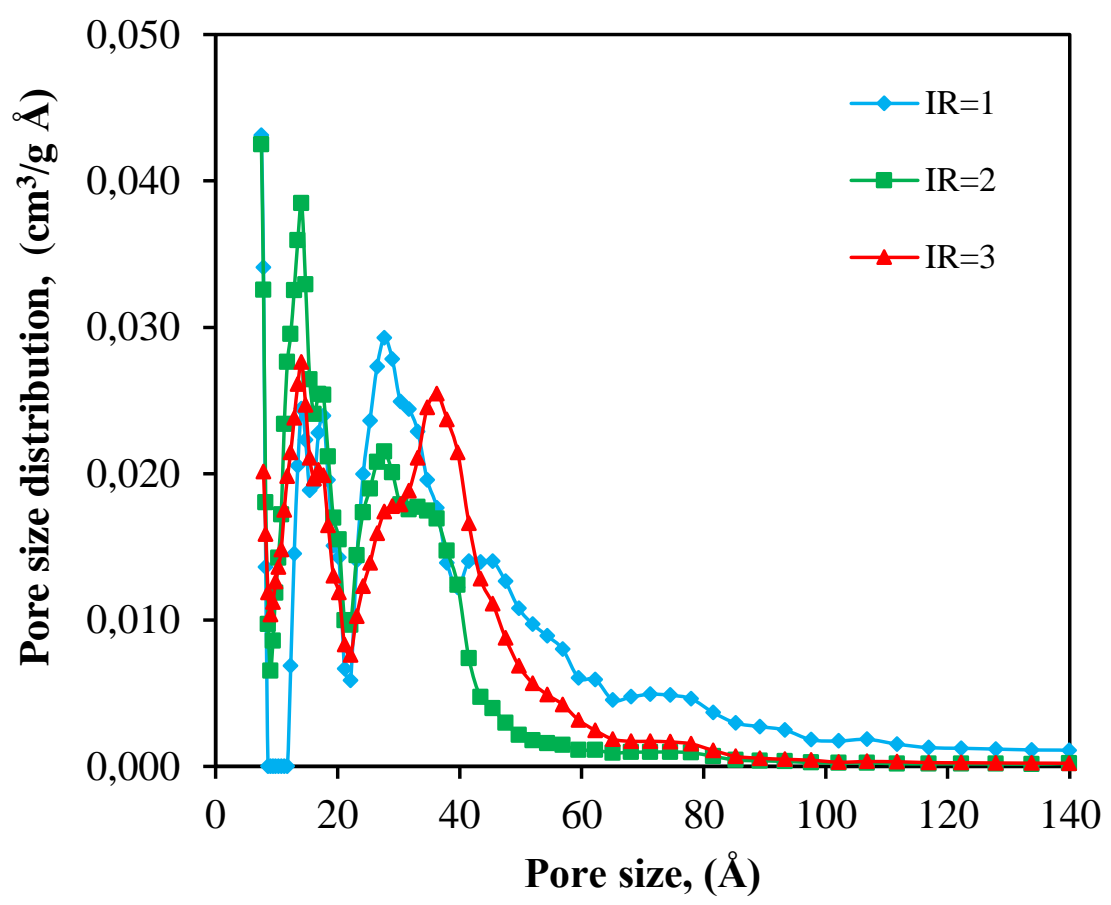

Figure 6. Pore size distribution of the activated carbons (activation temperature:500 ${ }^{\circ} \mathrm{C}$ )

\subsection{SEM Analyses of the Produced Activated Carbon}

Scanning electron microscopy (SEM) is widely used to study the surface morphology, including the pore structure, surface structure and pore arrangement on a material surface. The $\mathrm{H}_{3} \mathrm{PO}_{4}$ impregnation ratio and final activation temperature were effective in creating high surface area with well developed pores on the surface of the activated carbon. Scanning electron micrographs of the activated carbons prepared at different impregnation ratios and carbonization temperatures are shown in Figure 7, respectively. In the chemical activation process, the pore diameter and pore volume increase and new pores are created due to the reaction between carbon and the activating agent. The effect of impregnation ratio on the surface morphology at the constant temperature of $500{ }^{\circ} \mathrm{C}$ is shown in Figure $7 \mathrm{a}-\mathrm{b}-\mathrm{c}$. As the impregnation ratio was increased from 1 to 2, the pore diameter and pore volume increased, and new pores were created due to the reaction between carbon and the activating agent. This causes a further increase in the specific surface area of the activated carbon. Pore structure of the activated carbons are similar at the impregnation ratio of 2 and 3 as seen in Figure 7 a-b-c.

Depending on the activation temperatures, the porosity of the external surfaces of the activated carbons were developed. As seen in Figure $7 \mathrm{~d}$-e-f, the porous structure was not formed in the activated carbon prepared at the activation temperature of $400{ }^{\circ} \mathrm{C}$. The surface of the activated carbon was fairly smooth except for some occasional cracks. As the temperature was increased to $500{ }^{\circ} \mathrm{C}$, activation process was 
able to create pore structure within the carbon, indicating higher surface area. It seems that the pores and cavities on the surfaces of carbons resulted from the evaporation of the activating agent in this case is phosphoric acid during carbonization, leaving the space previously occupied by the activating agent [29,38]. Therefore, the $\mathrm{H}_{3} \mathrm{PO}_{4}$ is an effective activating agent to obtain activated carbon having high surface area. This observation can be supported by the BET surface area of the activated carbons as illustrated in Table 3.

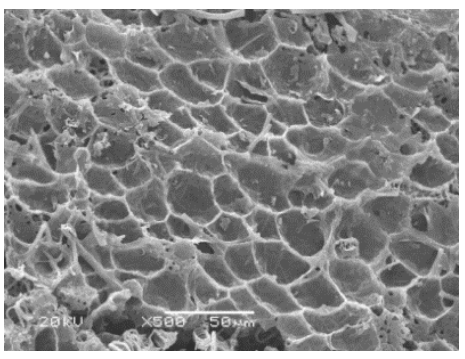

$\mathbf{a}$

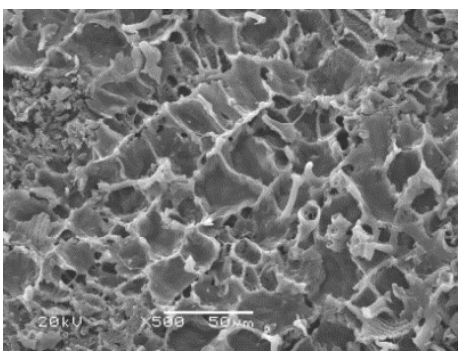

d

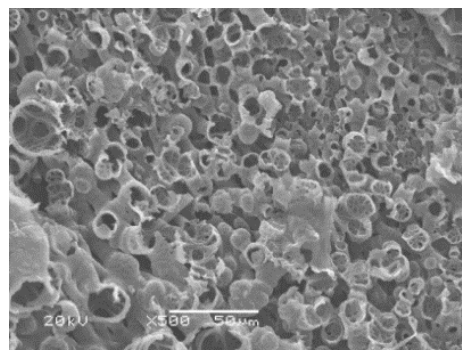

b

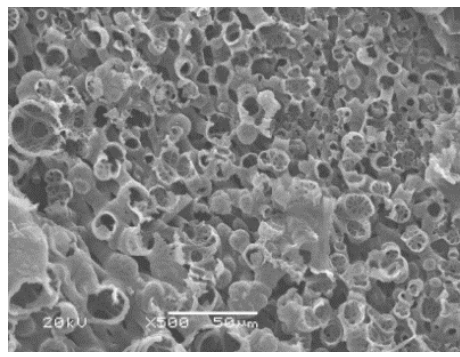

$\mathbf{e}$

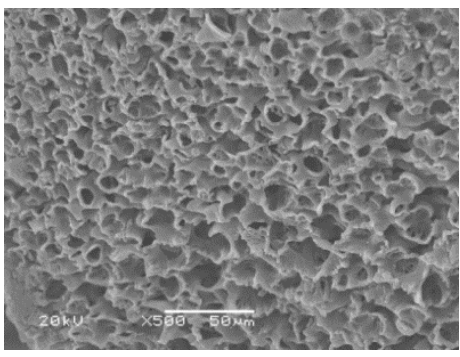

C

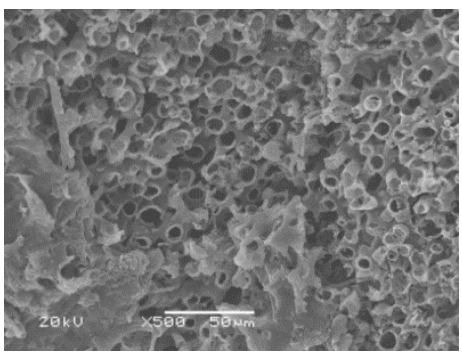

$\mathbf{f}$

Figure 7. Scanning electron micrographs of activated carbons prepared at different impregnation ratios (a) IR:1; (b) IR:2; (c) IR:3 (carbonization temperature:500 ${ }^{\circ} \mathrm{C}$ ) and different carbonization temperatures (d) $400^{\circ} \mathrm{C}$; (e) $500^{\circ} \mathrm{C}$; (f) $600^{\circ} \mathrm{C}$ (impregation ratio:2)

\subsection{FTIR Analyses of the Activated Carbon}

It is well known that activated carbons have a wide variety of surface functional groups. These groups are very important characteristics of the activated carbons, because they determine the surface properties of the activated carbon. The FTIR spectroscopy can provide basic spectra of activated carbons, especially for determination of types and intensities of their surface functional groups. FTIR spectra of pumpkin seed shell and activated carbons with an impregnation ratio of 2 at different activation temperatures are illustrated in Figure 8.

It was shown that the pumpkin seed shell precursor contained much more bands than the activated carbons, and there were only slight differences between the activated carbons. According to the results, it can be observed that there was disappearance of bands when comparing the raw material spectrum with the activated carbons spectra, indicating that the chemical bonds were broken during the carbonization process followed by the activation.

A wide absorption band at $3000-3600 \mathrm{~cm}^{-1}$ with a maximum at about $3290 \mathrm{~cm}^{-1}$ is assigned to $\mathrm{O}-\mathrm{H}$ stretching vibrations of hydrogen bonded hydroxyl groups. This peak is stronger for the pumpkin seed shell and has weakened for the activated carbons. The bands at 2930 and $2860 \mathrm{~cm}^{-1}$, which are assigned to asymmetric C-H and symmetric C-H bands, respectively, present in alkyl groups such as methyl and methylene groups, completely disappeared for the activated carbons [30]. Stretching absorption band at $1740 \mathrm{~cm}^{-1}$ is assigned to carbonyl $\mathrm{C}=\mathrm{O}$ present in esters, aldehydes, ketone groups and acetyl derivatives. This band almost disappeared in the activated carbons as seen in the figure. The strong band is seen at about $1640 \mathrm{~cm}^{-1}$ that may be ascribed to olefinic $\mathrm{C}=\mathrm{C}$ vibrations in aromatic region for the pumpkin 
seed shell [9]. Another strong band at $1030 \mathrm{~cm}^{-1}$ represents C-O stretching vibrations in the raw material. The band at approximately $1420 \mathrm{~cm}^{-1}$ can be attributed to $\mathrm{C}-\mathrm{H}$ stretching. The band at $1240 \mathrm{~cm}^{-1}$ confirms the presence of ester functional group [39]. The absorption bands in the region $450-750 \mathrm{~cm}^{-1}$ indicate the presence of alkynes and alkyl halides [40].

The FTIR spectra of carbons show small changes at $1560 \mathrm{~cm}^{-1}$ band and $1170 \mathrm{~cm}^{-1}$ band with different activated temperature. All the spectra exhibit a strong band around $1560 \mathrm{~cm}^{-1}$ due to combined stretching vibrations of conjugated $\mathrm{C}=\mathrm{O}$ group and aromatic rings. The strong bands located around $1170 \mathrm{~cm}^{-1} \mathrm{can}$ be attributed to the stretching vibration of hydrogen-bonded $\mathrm{P}=\mathrm{O}$ groups from phosphates or polyphosphates, the $\mathrm{O}-\mathrm{C}$ stretching vibration in the $\mathrm{P}-\mathrm{O}-\mathrm{C}$ (aromatic) linkage, and $\mathrm{P}=\mathrm{OOH}$ [41]. The shoulder at $1072 \mathrm{~cm}^{-1}$ can be ascribed to ionized linkage $\mathrm{P}^{+}-\mathrm{O}^{-}$in acid phosphate esters and to symmetrical vibration in a chain of $\mathrm{P}-\mathrm{O}-\mathrm{P}$.

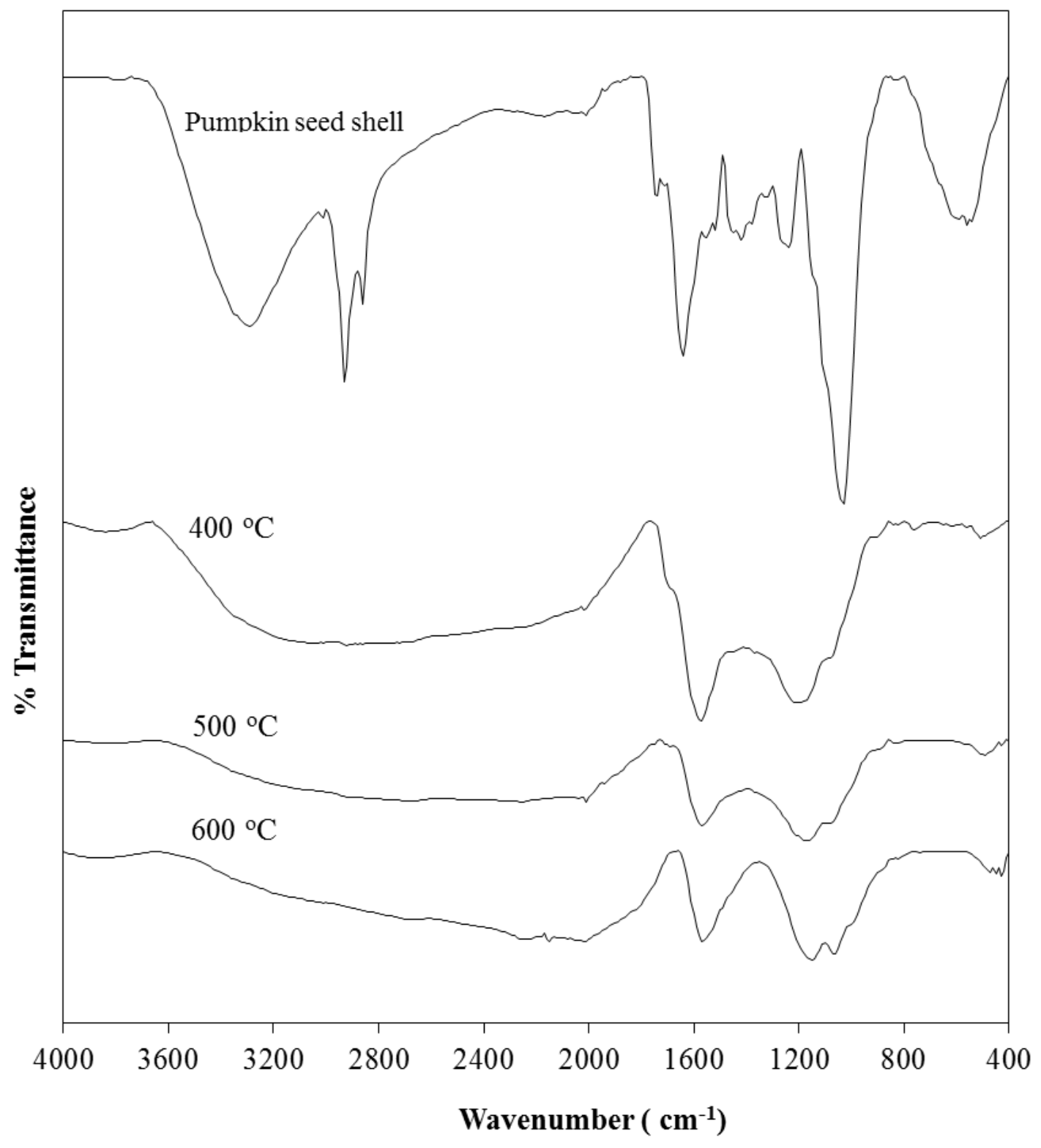

Figure 8. FTIR spectra of pumpkin seed shell, and activated carbons prepared from pumpkin seed shell with impregnation ratio of 2 at different activation temperatures 


\section{CONCLUSION}

Pumpkin seed shell was used as a raw material to prepare activated carbons by chemical activation method with $\mathrm{H}_{3} \mathrm{PO}_{4}$. The impregnation ratio and the final activation temperature had a significant effect on the development of porosity. The impregnation ratio of 2 and activation temperature of $500{ }^{\circ} \mathrm{C}$ were found as the optimum conditions to obtain activated carbon of high surface area from pumpkin seed shell. The maximum BET surface area and total pore volume were determined as $1421 \mathrm{~m}^{2} / \mathrm{g}$ and 0.908 $\mathrm{cm}^{3} / \mathrm{g}$, respectively. The pore size distribution shows that the activated carbons include both micropores and mesopores structures. It was found that pumpkin seed shell is a good precursor for activated carbon production.

\section{ACKNOWLEDGEMENT}

This study was financially supported by Eskişehir Osmangazi University Scientific Research Foundation (Project No: 201315A103).

\section{REFERENCES}

[1] Hayashi J, Kazehaya A, Muroyama K, Watkinson AP. Preparation of activated carbon from lignin by chemical activation. Carbon 2000; 38: 1873-1878.

[2] Alslaibi TM, Abustan I, Ahmad MA, Foul AA. A review: production of activated carbon from agricultural byproducts via conventional and microwave heating. J Chem Technol Biotechnol 2013; 88: $1183-1190$.

[3] Corcho-Corral B, Olivares-Marin M, Fernandez-Gonzalez C, Gomez-Serrano V, Macias-Garcia A. Preparation and textural characterisation of activated carbon from vine shoots (Vitis vinifera) by $\mathrm{H}_{3} \mathrm{PO}_{4}$ Chemical activation. Appl Surface Sci 2006; 252: 5961-5966.

[4] Tiryaki B, Yağmur E, Banford A, Aktaş Z. Comparison of activated carbon produced from natural biomass and equivalent chemical compositions. J Anal Appl Pyrol 2014; 105: 276-283.

[5] Lua AC, Yang T. Characteristics of activated carbon prepared from pistachio-nut shell by zinc chloride activation under nitrogen and vacuum conditions. J Colloid Interf Sci 2005; 290: 505-513.

[6] Okoye AI, Ejikeme PM, Onukwuli OD. Lead removal from wastewater using fluted pumpkin seed shell activated carbon: Adsorption modeling and kinetics. Int J Environ Sci Tech 2010; 7(4): 793-800.

[7] Olivares- Marin M, Gonzalez CF, Garcia AM, Serrano VG. Preparation of activated carbon from cherry stones by physical activation in air. Influence of the chemical carbonisation with $\mathrm{H}_{2} \mathrm{SO}_{4}$. $\mathrm{J}$ Anal Appl Pyrol 2012; 94: 131-137.

[8] Balathanigaimani MS, Shim WG, Kim C, Lee JW, Moon H. Surface structural characterization of highly porous activated carbon prepared from corn grain. Surf Interface Anal 2009; 41: 484-488.

[9] Gurten I, Ozmak M, Yagmur E, Aktaş Z. Preparation and characterisation of activated carbon from waste tea using $\mathrm{K}_{2} \mathrm{CO}_{3}$. Biomass Bioenerg 2012; 37: 73-81.

[10] Rosas JM, Bedia J, Mirasol JR, Cordero T. On the preparation and characterization of chars and activated carbons from orange skin. Fuel Process Technol 2010; 91: 1345-1354. 
[11] Yorgun S, Yildız D. Preparation and characterization of activated carbons from Paulownia wood by chemical activation with $\mathrm{H}_{3} \mathrm{PO}_{4}$. J Taiwan Inst Chem Eng 2015; 53: 122-131.

[12] Cazetta AL, Vargas MM, Nogami EM, Kunita MH, Guilherme MR, Martins AC, Silva TS, Moraes JCG, Almeida VC. $\mathrm{NaOH}$ activated carbon of high surface area produced from coconut shell: Kinetics and equilibrium studies from the methylene blue adsorption. Chem Eng J 2011; 174: 117-125.

[13] El-Hendawy ANA, Samra SE, Girgis BS. Adsorption characteristics of activated carbons obtained from corncobs. Colloids Surf 2001; 180: 209-221.

[14] Demiral H, Demiral İ, Tümsek F, Karabacakoğlu B. Pore structure of activated carbon prepared from hazelnut bagasse by chemical activation. Surf Interface Anal 2008; 40: 616-619.

[15] Hayashi J, Horikawa T, Takeda I, Muroyama K, Ani FN. Preparing activated carbon from various nutshells by chemical activation with $\mathrm{K}_{2} \mathrm{CO}_{3}$. Carbon 2002; 40: 2381-2386.

[16] Tseng RL. Physical and chemical properties and adsorption type of activated carbon prepared from plum kernels by $\mathrm{NaOH}$ activation. J Hazard Mater 2007; 147: 1020-1027.

[17] Uçar S, Erdem M, Tay T, Karagöz S. Removal of lead (II) and nickel (II) ions from aqueous solution using activated carbon prepared from rapeseed oil cake by $\mathrm{Na}_{2} \mathrm{CO}_{3}$ activation. Clean Techn Environ Policy 2015; 17: 747-756.

[18] Gerçel Ö, Gerçel HF. Adsorption of lead(II) ions from aqueous solutions by activated carbon prepared from biomass plant material of Euphorbia rigida. Chem Eng J 2007; 132: 289-297.

[19] Gerçel Ö, Özcan A, Özcan AS, Gerçel HF. Preparation of activated carbon from a renewable bioplant of Euphorbia rigida by $\mathrm{H}_{2} \mathrm{SO}_{4}$ activation and its adsorption behavior in aqueous solutions. Appl Surface Sci 2007; 253: 4843-4852.

[20] Angin D. Utilization of activated carbon produced from fruit juice industry solid waste for the adsorption of Yellow 18 from aqueous solutions. Bioresour Technol 2014; 168: 259-266.

[21] Şahin Ö, Saka C, Ceyhan AA, Baytar O. Preparation of high surface area activated carbon from Elaeagnus angustifolia seeds by chemical activation with $\mathrm{ZnCl}_{2}$ in one-step treatment and its iodine adsorption. Sep Sci Technol 2015; 50: 886-891.

[22] Diao Y, Walawender WP, Fan LT. Activated carbons prepared from phosphoric acid activation of grain sorghum. Bioresour Technol 2002; 81: 45-52.

[23] Ahmed MJ, Theydan SK. Physical and chemical characteristics of activated carbon prepared by pyrolysis of chemically treated date stones and its ability to adsorb organics. Powder Technol 2012; 229: 237-245.

[24] El Qada EN, Allen SJ, Walker EM. Influence of preparation conditions on the characteristics of activated carbons produced in laboratory and pilot scale systems. Chem Eng J 2008; 142: 1-13.

[25] Danish M, Hashim R, Ibrahim MNM, Sulaiman O. Optimization study for preparation of activated carbon from Acacia mangium wood using phosphoric acid. Wood Sci Technol 2014; 48: 1069-1083.

[26] Kunquan L, Zheng Z, Ye L. Characterization and lead adsorption properties of activated carbons prepared from cotton stalk by one-step of $\mathrm{H}_{3} \mathrm{PO}_{4}$ activation. J Hazard Mater 2010; 181: 440-447. 
[27] Stavropoulos GG, Zabaniotou AA. Production and characterization of activated carbons from oliveseed waste residue. Micropor Mesopor Mater 2005; 82: 79-85.

[28] Chandra TC, Mirna MM, Sunarso J, Sudaryanto Y, Ismadji S. Activated carbon from durian shell: Preparation and characterization. J Taiwan Inst Chem Eng 2009; 40: 457-462.

[29] Prahas D, Kartika Y, Indraswati N, Ismadji S. Activated carbon from jackfruit peel waste by $\mathrm{H}_{3} \mathrm{PO}_{4}$ chemical activation: Pore structure and surface chemistry characterization. Chem Eng J 2008; 140: 32-42.

[30] Yağmur E, Özmak M, Aktaş Z. A novel method for production of activated carbon from waste tea by chemical activation with microwave energy. Fuel 2008; 87: 3278-3285.

[31] Nahil MA, Williams PT. Pore characteristics of activated carbons from the phosphoric acid chemical activation of cotton stalks. Biomass Bioenergy 2012; 37: 142-149.

[32] Aygün A, Yenisoy-Karakaş S, Duman I. Production of granular activated carbon from fruit stones and nutshells and evaluation of their physical, chemical and adsorption properties. Micropor Mesopor Mater 2003; 66: 189-195.

[33] Yang R, Liu G, Xu X, Li M, Zhang J, Hao X. Surface texture, chemistry and adsorption properties of acidblue 9 of hemp (Cannabis sativa L.) bast-based activated carbon fibers prepared by phosphoric acid activation. Biomass Bioenergy 2011; 35: 437-445.

[34] Guo Y, Rockstraw DA. Physical and chemical properties of carbons synthesized from xylan, cellulose, and kraft lignin by $\mathrm{H}_{3} \mathrm{PO}_{4}$ activation. Carbon 2006; 44: 1464-1475.

[35] Patnukao P, Pavasant P. Activated carbon from Eucalyptus camaldulensis Dehn bark using phosphoric acid activation. Bioresource Technol 2008; 99: 8540-8543.

[36] Liu QS, Zheng T, Wang P, Guo L. Preparation and characterization of activated carbon from bamboo by microwave induced phosphoric acid activation. Ind Crops Prod 2010; 31: 233-238.

[37] Namane A, Mekarzia A, Benrachedi K, Belhaneche-Bensemra N, Helall A. Determination of the adsorption capacity of activated carbon made from coffee grounds by chemical activation with $\mathrm{ZnCl}_{2}$ and $\mathrm{H}_{3} \mathrm{PO}_{4}$. J Hazard Mater 2005; 119: 189-194.

[38] Ibrahim TH, Babar ZB, Khamis MI. Removal of lead (II) ions from aqueous solution using egg plant peels activated charcoal. Sep Sci Technol 2015; 50: 91-98.

[39] Vijayalakshmi P, Sathya Selva Bala V, Thiruvengadaravi KV, Panneerselvam P, Palanichamy M, Sivanesan S. Removal of acid violet 17 from aqueous solutions by adsorption onto activated carbon prepared from pistachio nut shell. Sep Sci Technol 2011; 46: 155-163.

[40] Mahapatra K, Ramteke DS, Paliwal LJ. Production of activated carbon from sludge of food processing industry under controlled pyrolysis and its application for methylene blue removal. J Anal Appl Pyrol 2012; 95: 79-86.

[41] Puziy AM, Poddubnaya OI, Martinez-Alonso A, Suarez-Garcia F, Tascon JMD. Surface chemistry of phosphorus-containing carbons of lignocellulosic origin. Carbon 2015; 43: 2857-2868. 